specially for the purpose. Thus Roumania will be represented by the seasonal hobby-horse dance performed by the Cališari with their heavy bells. The dance and its numerous seasonal parallels in other parts of Europe will be demonstrated and discussed by Prof. Vula. A Bulgarian theme, the 'spring maiden' of folk dance and song, will be analysed by Mme. Raina Katzarova, of the Ethnographical Museum, Sophia, who will illustrate her argument with movements by Bulgarian dancers. The interesting form of the sword dance found in Piedmont, with its singular combination with the maypole ritual and its resemblances in detail to the sword dance of Britain, will also be shown and afford an opportunity for comparison with a presentation of the Austrian sword dance, which has given evidence for an alternative explanation of the dance to that generally accepted. Britain, the Netherlands, France and Norway are among other countries providing material for discussion. The international folk-dance festivals which have been held in London in recent years have provided much interesting material for consideration, but on this occasion the conjunction of a conference dealing with study of the rituals, of which the dances preserve the evidence, should do much to advance the scientific study of this important department of primitive religion. The Conference will meet at the Cecil Sharp House, Regent's Park, London, N.W.1.

\section{North East Coast Institution of Engineers and Shipbuilders}

THw North East Coast Institution of Engineers and Shipbuilders will celebrate its jubilee on July 16-19 at Newcastle-on-Tyne. The Institution held its inaugural meeting on November 28, 1884, and from then until the present time has been one of the most active bodies concerned with the advancement of the sciences of engineering and shipbuilding not only in Great Britain, but also throughout the world. Representatives will attend the meeting from the leading British kindred societies and allied bodies, and also from France, Germany, Holland, Italy, Japan and the United States. The papers to be presented at the meeting will deal with the history of engineering during the past fifty years in the following sections : liners, cargo ships and tankers, coasters, marine turbines, reciprocating steam engines, marine boilers, marine heavy-oil engines, and recent progress in electrical and general engineering. Dr. John T. Batey will preside at the meetings. A pleasurable feature will be the presentation of acknowledgments to founder members. Notable among these are Sir George B. Hunter, Mr. J. Denham Christie, Prof. R. L. Weighton and Mr. W. G. Spence (the initiator and first honorary secretary of the Institution). The honorary fellowship of the Institution will be conferred upon the following : Mr. George Stephen Baker, superintendent of the William Froude Laboratory; Vice-Admiral Sir Harold A. Brown, engineer-inchief of the Fleet; Sir Cecil Algernon Cochrane, chairman of Armstrong College Council, 1923-35; and Sir Arthur William Johns, director of naval construction.

\section{Ultra-Violet Transmitting Glass}

Speormens of ultra-violet transmitting plate glass produced by Messrs. Pilkington Brothers Ltd., of St. Helens, Lancashire, show a region of high transmission in the region near $3650 \mathrm{~A}$., with an almost complete opacity to the visible spectrum except in the extreme violet, where the transmission is, however, said to be only about 1 per cent. Tested with a powerful spark source and a monochromator, the claims of the makers were found to be justified. The transmission in the ultra-violet was comparable with that of an 'ultra-violet' glass from another source, the cadmium line near $3610 \mathrm{~A}$. being freely transmitted; but whereas Messrs. Pilkington's new glass showed no transmission in the visible region when tested with a pocket spectroscope, the other glass showed a marked transmission band in the red. The glass can be manufactured in large sizes ; specimens have been submitted of thickness $8 \mathrm{~mm}$. and $11 \mathrm{~mm}$. respectively. In view of the increasing importance of fluorescence tests, and other applications of ultraviolet radiation, numerous uses should be found for it, since its opacity to visible radiations should facilitate the distinction between genuine fluorescence and effects of reflected light. It may be worth noting that in very thin layers this new glass is of a blue-green colour. A prism of small angle ground to a very thin edge should make a very pretty example of dichromatism.

\section{Scent and the Weather}

Hitherto, success in hunting has depended largely on popular omens of hunting conditions and on the practical experience of Masters of Hounds. The relation of scent and the weather formed the subject of a recent scientific study (see Nature, April 14, 1934 , p. 548). Now a meteorological officer of the Royal Air Force (R. G. Veryard) has supplied information enabling the Master to arrange place and time of meet to fit in with the best scenting conditions. In a pamphlet issued by the Masters of Foxhounds Association of India (Lieut.-Col. C. J. R. Turner, 47th Sikhs, Chaman, Baluchistan. 3 rupees), although specially written for the Peshawar Vale Hunt, he discusses many points which are of more than local interest. An inversion, or low lapse-rate of temperature, involving a restriction of the upward motion of eddies, is mainly favourable for good scenting conditions. The author does not agree with Mr. Budgett's view that for scenting conditions to be good the ground must always be warmer than the air, because a superadiabatic lapse-rate near the ground causes atmospheric turbulence which dissipates even scents which were quite strong initially. The number of good and bad scenting days are approximately equal during a calm, but, with a moderate wind, up to 3 on the Beaufort scale, the rate of evaporation is increased and scent may be good. If the air is less than 30 per cent saturated, scenting conditions are likely to be poor. Scent is more likely to be good if the soil is moist than if it is dry. The best hunting conditions in Peshawar obtained when the air temperature registered between $40^{\circ}$ and $65^{\circ} \mathrm{F}$., 